chief executive offeer of the British Medical Association, by propusing alterations in nearly one-half of its laws. As a member of the Council, I addressed you officially on the broadest public grounds on that issue; and, so far as I am concerned, the discussion shall be conducted with the most faithful observance of those rules which make a free expression of differences of opinion possible amongst gentlemen.

I abstain from expressing any opinion on the judgment, taste, and discretion displayed by your subordinate officer, in commenting on our correspondence in the terms quoted, but I submit for your consideration whether the editorial article in question does not furnish additional evidence against the expediency of further centralisation of power in the British Medical Association.

I am, dear Sir, faithfully yours,

To William D. Husband, Esq., F.R.C.S., J.P., SAMPSON GAMGEE.

President of the Council of the British Medical Association.

36, Bootham, York, July 3rd, 1871.

MY DEAR SIR,-I beg to acknowledge the receipt of your letter in which you complain of the article appended to our correspondence in the British Medical Journal, and to assure you that the Committee of Council have no intention of giving increased power or influence to the editor of the Journal in the management of the Association.

Believe me, yours very truly,

To Sampson Gamgee, Esq., F.R.S.E. W. D. Husband.

\section{THERAPEUTICS AND PATHOLOGY.}

To the Editor of THE LANCET.

SiR,-From some of the remarks made by Dr. Wade in his very sensible lecture on Functional Medicine, one is led to infer that it is usually considered a kind of humiliation and derogation of dignity for a scientific physician to say that he treats symptoms. Why this should be, I cannot see; for in the art of medicine, as in most other arts, we have to deal with things as they appear before us, and commonly to deal promptly and unhesitatingly, lest the manifest evil gain ground and become irremediable.

As I have just said, this same principle of action applies to other arts than that of medicine. Take engineering, for example. A railway arch may show cracks and symptoms of giving way; then surely the first duty of the engineer is to secure the arch as best he can with the means at his command against further mischief, while he may well enough reserve the question as to the nature of the soil underlying the foundation till the immediate danger is averted. It may be interesting and instructive to discover on investigation some as yet unknown peculiarity in the subsoil which has cansed a settlement and fracture of the arch, but at first the most important thing is to deal with the urgent and threatening symptoms. Similar illustrations might be taken from other kinds of art, but one is enough.

Generally it seems in physic that a man's confidence in drugs is inversely as his pathological knowledge. Great morbid anatomists are usually reputed very sceptical as to the power of drugs to heal, while on the other hand implicit faith in the curative power of physic appears to belong to those who hardly know what morbid anatomy means.

Old women, as Bacon very sagaciously used to say, are the formidable competitors of the physician, and the reason may be that they are more religious in their faith in the physic they give; they are strong in drug-healing faith, while of pathology they know nothing.

For my own part I must say I cannot at all see why the study of patbology, dead-meat pathology I nean, should cause scepticism in the healing powers of drugs. I regard this sort of pathology as an interesting science, showing what will occur in disease that is negleoted, badly treated, or that, as yet, cannot be treated by any known remedy. Morbid products are to be held forth as a wholesome warning of what will happen if our therapeutics fail; further than this the mere study of dead meat in plates has no more bearing on actual everyday therapeutics than the study of minerals or fossils would have. A lung excavated into a mere bag of pus is an object of curiosity and interest, and one is naturally inclined to smile at the idea of curing such a lung by creasote, quinine, or cod-liver oil; but then we don't regard the lung spread out on a piate with any reierence to such a cure. We, if pure morbid anatomists merely, pass it on; or, if therapeutically disposed, we endeavour to follow the history back into the land of symptoms, and especially of early symptoms, and then see, as opportunities offer, how far these can be met by remedies. And here we have the true art of medicine-not a mere guess-work of empiricism, but an art based on observation, and supported by science.

I am, Sir, yours obediently,

Welbeck-street, W., July 1st, $1871 . \quad$ JoHN C. THOROWGOOD.

MANCHESTER.

(FROM OUR OWN CORRESPONDENT.)

SrNCE my last communication, small-pox has been gradually extending in Manchester and Salford, and seems now to be generally prevalent in all parts of the city. The increase bas been most marked in the township of Hulme, where, for the last ten days, a number of fresh cases have been reported daily. The neighbouring village of Eccles has also been invaded, and has suffered very considerably, sixteen deaths having been reported to the Board as having taken place during the last month. Fortunately, however, the epidemic has not assumed a dangerous form in general, most of the cases being of a mild character; thus, although in the public practice alone of Manchester and Salford during the week ending 17 th June, 72 fresh cases are reported, being the largest number hitherto returned, the total number of deaths supplied to the registrar during the same week amounted to eight. The available wards in the Royal Infirmary are, it is said, fully occupied, and it is gratifying to find that the Chorlton Board of Guardians have at length provided adequate accommodation for the reception of small-pox cases, of which there are at present about forty in the workhouse. It had been for some time notorious that the wards in use for such cases were about as ill-adapted for the purpose as they could well be; one of them being used as a kind of clothes-store, and being situated just over the general receiving-room. They were visited by Mr. Basil Cane, the Poor-law inspector for the district, on the 27 th ult. On receiving his report, the guardians resolved to adopt his suggestion to convert one of the pavilions into a small-pox hospital.

The epidemic of measles has disappeared from certain districts, but it continues to swell the mortality returns in Salford especially, and also in some portions of Manchester.

The excellent article of your special reporter which appears in to-day's I IANCE'S, has received much commendation; it, however, contains a slight inaccuracy which ought to be rectified. It is said, with reference to the Manchester Royal Infrmary, that ovariotomy is rarely performed; it has, however, been by no means a rare operation of late, several of the surgcons having had cases, a successful issue of which has been not infrequent. It is hoped in a future communication to give statistics on this point. Your reporter has said, with truth, that there is no special officer for the diseases of women; this is scarcely to be regretted, as there is a special hospital for the reception of such cases within a short distance of the infirmary. There are, however, rumours of a proposed amalgamation scheme in this direction, which, if carried out, will greatly conduce to the efficiency of medical education in Manchester.

Manchester, July lst, 1871.

IRELAND.

(FROMI OUR OWN CORRESPONDENT.)

TYPUUS FEVER AT THE CURRAGH.

I HAVस been given to understind that typhus fever has made its appearance again this year at the Curragh Camp, and that several parties hare been attacked, principally owing to the arrangements for the utilisation of the sewage, which is retained in an open reservoir, thereby polluting 